\title{
Decentralization of health systems in Latin America
}

\author{
Thomas Bossert, ${ }^{1}$ Osvaldo Larrañaga, ${ }^{2}$ and Fernando Ruiz Meir ${ }^{3}$
}

\begin{abstract}
Decentralization is often a major part of health reform policies. However, there have been few attempts to comparatively study the degree of decentralization and the effects of decentralization on equity of allocations to health, so we do not know how best to implement this reform. This article uses an innovative comparative analysis of the "decision space" that was allowed to local municipalities in the health reforms of Bolivia and Chile, two countries that have had several years of experience in implementing decentralization. The studies found that relatively little decision space was allowed to local authorities over key functions of health care systems. The studies also found that central authorities often reduce the decision space in order to direct more resources to health or to restrict local choice over human resources issues. The studies found that more equitable allocations of health funding were achieved through a common equalization fund for the municipalities in Chile and by forcing the assignment to health of a specific percentage of the central government transfers to municipalities in Bolivia.
\end{abstract}

In Latin America, decentralization is a major component of many new policies of health reform. Such large countries as Brazil and Mexico, as well as such smaller countries as Bolivia and Guatemala, have initiated major reforms in decentralization (1-3). While decentralization has been enthusiastically embraced by many health reformers as a goal in itself, there is growing concern that decentralization may not achieve the major goals of health reform, such as improved eq-

\footnotetext{
1 Harvard School of Public Health, Boston, Massachusetts. Send correspondence to: Thomas Bossert, Harvard School of Public Health, 665 Huntington Avenue, I-1210, Boston, Massachusetts 02115 , United States of America; e-mail: tbossert@hsph. harvard.edu

2 Universidad de Chile, Santiago, Chile.

3 KPMG Bolivia, La Paz, Bolivia.
}

uity of access and coverage, gains in efficiency in the use of resources, improved quality, and sustained financial soundness (4-6). It is clear that the crucial elements of effective decentralization are still poorly understood.

As part of the Latin American and the Caribbean Initiative for Health Sector Reform sponsored by the U.S. Agency for International Development, the Data for Decision Making Project, at the Harvard School of Public Health, has developed a unique approach to the evaluation of the decentralization of health systems.

The usual approach to decentralization evaluation has emphasized the institutional arenas in which new responsibilities and authorities have been granted. This approach distinguishes between "devolution" and "deconcentration." Devolution transfers authority to provincial, state, or municipal governments, while deconcentration shifts authority to regional and district offices within the ministry of health.

The approach we use in our analysis focuses on how much choice is shifted to the different organizations. Using a "principal-agent" orientation, we view decentralization as a means by which the central authorities (principals) attempt to improve health systems by shaping the choices and incentives of the decentralized units (agents), so that the agents make appropriate choices toward the principals' objectives. This approach assists policymakers in the design of an appropriate framework for decentralization and shows them how different ranges of choice by local decisionmakers may result in programs and activities that better achieve general na- 
tional objectives of equity, efficiency, quality, and financial soundness.

Called the "decision-space approach," this method focuses on defining the range of choice (narrow to wide) over a specified series of functions (financing, service organization, human resources, targeting, and governance) that is allowed to local decisionmakers (7). Each system is significantly different, and the "decision space" allowed to local decisionmakers varies from country to country and changes over time. A general "map" for this approach is shown in Figure 1.

Our approach attempts to establish a link among the range of choices available to local officials, the choices they make-in particular the innovative choices-and the effects of these choices on the performance of the decentralized system. For instance, if a local government adds its own resources to the health system, do these new resources improve the equity, efficiency, quality, and financial soundness of the local system?

\section{APPLIED RESEARCH IN BOLIVIA AND CHILE}

Using this approach, our project has chosen local teams of researchers to implement applied research evaluations of the decentralization experiences in Bolivia, Chile, and Colombia. These studies have collected and analyzed nationally available data on income and expenditures, human resources, utilization of public health services, and social and economic conditions.

This article briefly reports on the first two completed studies, on Chile for the 1990-1996 period (8) and Bolivia for the 1994-1996 period (9).

The process of decentralization in Chile began in the early 1980s and transferred to municipal governments the ownership of primary care facilities and decisions on human resources. Financing for health facilities came from a national fund that assigned resources according to a negotiated ceiling on fees for service charges. That fund was supplemented by local municipal government resources.

\section{A descentralização no marco da Reforma Sanitária no Brasil}

\author{
Luiz Odorico Monteiro de Andrade, ${ }^{1}$ \\ Ricardo José Soares Pontes ${ }^{2}$ e Tomaz Martins Junior ${ }^{3}$
}

\section{Do nascimento da saúde pública ao Movimento da Reforma Sanitária}

O nascimento da saúde pública no Brasil deu-se na transição do século XIX para o século XX, no período compreendido entre o fim da monarquia e o início da "República Velha". Configurou-se em um processo de elaboração de normas e organizações sanitárias e de mudança nas práticas dominantes até então. Ficou conhecido como "sanitarismo campanhista", foi marcante nos estados de Rio de Janeiro e São Paulo, visou principalmente sanear os espaços de circulação das mercadorias exportáveis e predominou até meados dos anos 60 .

Na década de 20 surgem, no bojo da industrialização incipiente, as Caixas de Aposentadoria e Pensões, que são substituídas na década de 30 pelos Institutos de Aposentadoria e Pensões, unificados na década de 60 para criar o Instituto Nacional de Assistência Médica e Previdência Social. Esta situação compõe os marcos administrativos nas políticas de saúde pública no Brasil de 1923 a 1975, período em que é possível evidenciar a duplicidade assistência/previdência, caracterizada pelo privilégio exercido pela prática médica curativa, individual, assistencialista e especializada, em detrimento da saúde pública, bem como o desenvolvimento de um sistema que priorizava a capitalização da medicina e a sua produção privada.

Em 1975, a Lei 6229 organiza o Sistema Nacional de Saúde e estabelece as principais competências das distintas esferas de governo. Essa organização tinha forte característica centralizadora no nível federal e nítida dicotomia entre as ações coletivas (competência do Ministério da Saúde) e individuais (competência do Ministério da Previdência e Assistência Social), o que fazia com que não se estabelecesse um comando único em cada esfera de governo. No nível federal, além das competências do Ministério da Previdência e Assistência Social e do Ministério da Saúde, também se definiam competências para os Ministérios da Educação, do Trabalho e do Interior.

Esse sistema recebeu fortes críticas de setores acadêmicos (Universidades, Departamentos de Medicina Preventiva e Social e Escolas de Saúde Pública) e de setores da sociedade civil. Já na década de 80, principalmente a partir de 1985, no interior do processo de redemocratização do país, deu-se o nascimento de um considerável movimento de múltiplos atores políticos chamado Movimento da Reforma Sanitária.

\footnotetext{
1 Secretaria de Saúde e Assistência Social de Sobral, Ceará, Brasil. E-mail: odorico @sobral.ce.gov

2 Departamento de Medicina Preventiva, Universidade Federal do Ceará, Ceará, Brasil.

3 Secretaria de Saúde e Assistência Social de Sobral, Ceará, Brasil.
} 
FIGURE 1. Standard decision-space map

\begin{tabular}{|c|c|c|c|}
\hline \multirow[b]{2}{*}{ Function } & \multicolumn{3}{|c|}{ Range of choice } \\
\hline & Narrow & Moderate & Wide \\
\hline \multicolumn{4}{|l|}{ Finance } \\
\hline Sources of revenue & $\Leftarrow$ & $\Leftarrow \Rightarrow$ & $\Rightarrow$ \\
\hline Allocation of expenditures & $\Leftarrow$ & $\Leftarrow \Rightarrow$ & $\Rightarrow$ \\
\hline Income from fees and contracts & $\Leftarrow$ & $\Leftarrow \Rightarrow$ & $\Rightarrow$ \\
\hline \multicolumn{4}{|l|}{ Service Organization } \\
\hline Hospital autonomy & $\Leftarrow$ & $\Leftarrow \Rightarrow$ & $\Rightarrow$ \\
\hline Insurance plans & $\Leftarrow$ & $\Leftarrow \Rightarrow$ & $\Rightarrow$ \\
\hline Payment mechanisms & $\Leftarrow$ & $\Leftarrow \Rightarrow$ & $\Rightarrow$ \\
\hline Contracts with private providers & $\Leftarrow$ & $\Leftarrow \Rightarrow$ & $\Rightarrow$ \\
\hline Required programs/norms & $\Leftarrow$ & $\Leftarrow \Rightarrow$ & $\Rightarrow$ \\
\hline \multicolumn{4}{|l|}{ Human resources } \\
\hline Salaries & $\Leftarrow$ & $\Leftarrow \Rightarrow$ & $\Rightarrow$ \\
\hline Contracts & $\Leftarrow$ & $\Leftarrow \Rightarrow$ & $\Rightarrow$ \\
\hline Civil service & $\Leftarrow$ & $\Leftarrow \Rightarrow$ & $\Rightarrow$ \\
\hline \multicolumn{4}{|l|}{ Access rules } \\
\hline Targeting & $\Leftarrow$ & $\Leftarrow \Rightarrow$ & $\Rightarrow$ \\
\hline \multicolumn{4}{|l|}{ Governance rules } \\
\hline Local government & $\Leftarrow$ & $\Leftarrow \Rightarrow$ & $\Rightarrow$ \\
\hline Facility boards & $\Leftarrow$ & $\Leftarrow \Rightarrow$ & $\Rightarrow$ \\
\hline Health offices & $\Leftarrow$ & $\Leftarrow \Rightarrow$ & $\Rightarrow$ \\
\hline Community participation & $\Leftarrow$ & $\Leftarrow \Rightarrow$ & $\Rightarrow$ \\
\hline
\end{tabular}

O grande marco histórico nesse processo foi, sem dúvida alguma, a VIII Conferência Nacional de Saúde, ocorrida em março de 1986, que contou com a participação de diversos setores organizados da sociedade e na qual houve um consenso de que para o setor da saúde no Brasil não era suficiente uma mera reforma administrativa e financeira, mas sim uma mudança em todo o arcabouço jurídico-institucional vigente, que contemplasse a ampliação do conceito de saúde segundo os preceitos da reforma sanitária. $\mathrm{O}$ relatório produzido nessa Conferência serviu de referência para os constituintes que elaboraram a Constituição de 1988.

\section{O nascimento do Sistema Único de Saúde (SUS)}

A Carta de 1988 enunciou as seguintes garantias para sistematização das ações e dos serviços destinados à promoção, proteção, preservação e recuperação da saúde individual e coletiva: a) a saúde como um direito de cidadania e dever do Estado; b) a relevância pública das ações e serviços de saúde; c) a universalidade da cobertura e do atendimento, tendo como princípio a eqüidade da assistência; d) a descentralização da gestão administrativa com garantia de participação comunitária; e) a integração da rede pública de serviços num sistema único; f) a possibilidade de participação complementar do setor privado de 
There are 334 municipalities in Chile, half with fewer than 17111 inhabitants, while $68.6 \%$ of the total population lives in the largest $20 \%$ of the municipalities. The initially wide choice allowed to localities for human resources decisions was significantly restricted in 1995 by a national statute that reimposed some of the key limitations of the original national civil service policies, including salary ranges and career path provisions. In addition, the negotiated ceiling for municipal funding was replaced by a per capita formula imposed by the Ministry of Health.

In Bolivia in 1994 new legislation transferred the budget for supplies and investments for all sectors to the control of the 312 municipalities. The majority of those municipalities had not existed before and were created by the new law; this was especially true in rural areas. In addition, mechanisms were installed for popular participation of nongovernmental organizations, called territorial base organizations. Human resource management remained centralized. After it became apparent that local governments were not allocating sufficient resources to health, in 1996 the national Government earmarked $3 \%$ of the municipal transfers for the Maternal and Child Health Insurance Program, which specified a basic care package that was to be available without fees.

In general it can be concluded that decentralization in Chile and Bolivia has not brought a particularly wide range of choice to local decisionmakers. Choice may be allowed for one function, such as allocation of expenditures, but other restrictions, such as control of human resources or strict norms for specific programs, limit the actual range of choice. In some areas in both countries, initially wide choice was narrowed over time.

Figure 2 shows a decision-space map for Chilean municipalities in 1996. In contrast, a map for 1988 would have shown wider choice over human resources, as well as sources of revenue and allocation of expenditures. Between 1988 and 1996, a new statute on human resources was passed serviços no sistema público de saúde; g) o co-financiamento dos orçamentos da União, dos Estados, do Distrito Federal e dos Municípios; h) a direção única nas esferas de governo (União, Estados, Distrito Federal e Municípios); i) a saúde como resultante de políticas sociais e econômicas e de fatores que determinam e condicionam o estado de bem-estar físico, mental e social do indivíduo.

O grande desafio do Movimento da Reforma Sanitária passou a ser promover a transição do sistema desintegrado, no que diz respeito à articulação das esferas de governo, e centralizado, ora em serviços médicos hospitalares privados, ora em programas verticalizados, para um outro sistema com comando único em cada esfera de governo. Aqui não mais uma tarefa de resistência, mas uma tarefa construtiva.

Um processo pactuado. No início da década de 90 o que se observa é que todo o processo de regulamentação do SUS já passa a contar não apenas com os atores do então Movimento Sanitário, mas também com novos atores que entram em cena, como os Secretários Municipais de Saúde, liderados pelo Conselho Nacional de Secretários Municipais de Saúde (CONASEMS), e os Secretários Estaduais de Saúde, liderados pelo Conselho Nacional de Secretários de Saúde (CONASS). Foi dando continuidade a este movimento que se iniciou todo o processo de pactuação infraconstitucional, onde se publicou a chamada Lei Orgânica da Saúde Brasileira, que é composta de duas Leis Complementares à Constituição (as Leis 8080/90 e 8142/90). A Lei 8080/90 disciplina a descentralização político-administrativa do SUS, enfatizando seus aspectos de gestão e financiamento, e regulamentando as condições para sua promoção, proteção e funcionamento. A Lei 8142/90 regulamenta a participação da comunidade, bem como as transferências intergovernamentais de recursos financeiros.

Como forma de regulamentar esta transição entre o antigo modelo organizacional e o SUS, o Ministério da Saúde vem utilizando instrumentos normativos que são publicados com o objetivo de regular as transferências de recursos financeiros da União para os Estados e Municípios, o planejamento das ações de saúde e os mecanismos de controle social. Estes instrumentos são as Normas Operacionais Básicas (NOB). Até o momento foram publicadas quatro NOB: 01/91, 01/92, 01/93 e 01/96. As NOB são, acima de tudo, produto da necessidade de um processo político de pactuação intergestores que, após a publicação da Lei Orgânica da Saúde, vem criando condições privilegiadas de negociação para viabilizar a descentralização e construção do SUS.

Ainda como forma de garantir a flexibilidade do processo de descentralização e respeitar a diversidade das realidades municipais e estaduais, foram asseguradas instâncias de negociação e pactuação entre os gestores do SUS: para os Estados, as Comissões Intergestores Bipartites, integradas por representantes de técnicos das Secretarias Estaduais e representantes dos municípios, indicados por integrantes do Conselho de Secretários Municipais de Saúde de cada Estado, e para a União, a Tripartite, composta por cinco técnicos do Ministério da Saúde, cinco Secretários Estaduais de Saúde indicados pelo CONASS e cinco representantes dos Secretários Municipais de Saúde indicados pelo CONASEMS. 
Outro ganho deste sistema foi a instalação das instâncias de participação social: os Conselhos Municipais, Estaduais e Nacional de Saúde. Hoje há um Conselho Nacional de Saúde com caráter deliberativo, vinte e sete Conselhos Estaduais de Saúde e mais de cinco mil Conselhos Municipais de Saúde.

A municipalização plena. A atual NOB em vigor é a 01/96, que estabeleceu como uma de suas finalidades prioritárias a transformação do modelo de atenção à saúde que até então era hegemônico. Enfatizou que isso implicava no aperfeiçoamento da gestão dos serviços de saúde no país e na própria organização do sistema, visto que o município passou a ser, de fato, responsável imediato pelo atendimento das necessidades e demandas de saúde de sua população e das exigências de intervenções saneadoras em seu território. Como tema principal estabeleceu a "Gestão plena com responsabilidade pela saúde do cidadão", buscando construir a plena responsabilidade do poder público municipal sobre a gestão de um sistema de saúde, e não somente sobre a prestação de serviços de saúde. Para isso, criou duas categorias de gestão: a Gestão Plena da Atenção Básica e a Gestão Plena do Sistema Municipal.

A primeira credencia o gestor municipal para, prioritariamente, elaborar a programação municipal dos serviços básicos, gerir unidades ambulatoriais próprias e contratar, controlar, auditar e pagar aos prestadores de serviços, procedimentos e ações de assistência básica. A segunda propicia ao gestor a possibilidade de elaborar toda a programação municipal, inclusive a de prestação de assistência ambulatorial especializada e hospitalar, conferindo assim aos municípios a ampliação de sua responsabilidade no tocante às necessidades da população.

A NOB-SUS 01/96 introduziu a idéia de SUS municipal, que, na prática, não difere muito das situações anteriores em que se procurou fortalecer o sistema local de saúde integrando uma rede regionalizada e hierarquizada. Esta norma definiu, de forma clara e precisa, a diferença conceitual entre gerência e gestão. Assim, a gerência foi conceituada como a "administração de uma unidade ou órgão de saúde (ambulatório, hospital, instituto, fundação etc.), que se caracteriza como prestador de serviços ao sistema", e a gestão como a "atividade e a responsabilidade de dirigir um sistema de saúde (municipal, estadual ou nacional) mediante o exercício de funções de coordenação, articulação, negociação, planejamento, acompanhamento, controle, avaliação e auditoria".

Em relação à necessidade de integração dos Sistemas Municipais de Saúde, preocupação que vem sendo mantida desde que a NOB 01/91 criou a figura dos consórcios intermunicipais, a NOB 01/96 foi taxativa: "os sistemas municipais de saúde apresentam níveis diferentes de complexidade, sendo comum estabelecimentos ou órgãos de saúde de um município atender usuários encaminhados por outro. As negociações destas referências devem ser efetivadas, exclusivamente, entre os gestores municipais". A NOB entendeu que esta relação, mediada pelo Estado, tem como instrumento de garantia uma programação pactuada e integrada nas Comissões Intergestores Estaduais e submetida aos Conselhos de Saúde correspondentes. and a per capita formula was put into place to determine the source of revenue from central transfers.

The Bolivian decision-space maps would appear similar. For most functions the range of choice is narrow to moderate. Choice over expenditures was later limited by the imposition of the 3\% earmark for the Maternal and Child Health Insurance Program.

Preliminary findings from these studies suggest that the current degrees of decentralization have not produced major changes in performance, as measured by available data on equity, efficiency, quality, and financial soundness. Decentralization has not been the panacea that advocates have claimed nor the disaster that detractors have suggested. Nevertheless, there have been some differences worth noting between the two countries.

In Chile the resources available for primary health care at the municipal level come mainly from three sources: central government transfers, an equalization fund of transfers from wealthier to poorer municipalities, and local revenues (8). Table 1 provides information according to the income decile of municipalities and shows the allocation from the central government and from local revenues; the figures for the local revenues include the reallocation from the equalization fund. The table shows that the central government contribution and the local contribution for primary health care for the lower nine deciles were relatively constant. Nevertheless, the richest municipalities allocated, from their own source revenues, four times as much per capita as did the other municipalities. This inequity may have reflected historical differences in spending that existed before decentralization. Decentralization appears not to have increased the level of inequality; indeed, the study found that the gap between wealthier and poorer localities declined over the 1991-1996 period.

The Chile research also found a significant correlation between the municipal expenditure per beneficiary and the level of municipal revenue 
FIGURE 2. Formal decision-space map, primary health care in Chilean municipalities, 1996

\begin{tabular}{|c|c|c|c|}
\hline \multirow[b]{2}{*}{ Functions } & \multicolumn{3}{|c|}{ Range of Choice } \\
\hline & Narrow & Moderate & Wide \\
\hline \multicolumn{4}{|l|}{ Financing } \\
\hline Expenditures & & $\begin{array}{l}\text { Allocations limited by salary and } \\
\text { hiring constraints since salary } \\
\text { expenditures are a high } \\
\text { proportion of primary health } \\
\text { care expenditures. }\end{array}$ & \\
\hline Income from fees & No fees for municipal services & & \\
\hline \multicolumn{4}{|l|}{ Service organization } \\
\hline Payment mechanisms & & Salary bonuses allowed & \\
\hline Required programs and norms & Determined by national health service & & \\
\hline \multicolumn{4}{|l|}{ Human Resources: } \\
\hline Salaries & $\begin{array}{l}\text { New statute established central } \\
\text { norms for salaries }\end{array}$ & & \\
\hline Contracts & & Contracts limited by statute & \\
\hline Civil service & $\begin{array}{l}\text { Statute establishes new civil service } \\
\text { for municipal health workers }\end{array}$ & & \\
\hline $\begin{array}{l}\text { Facility boards } \\
\text { Health offices }\end{array}$ & & $\begin{array}{l}\text { Two options for primary health care } \\
\text { facility governance and health } \\
\text { offices }\end{array}$ & \\
\hline Community participation & & & $\begin{array}{l}\text { Community participation at } \\
\text { discretion of municipality }\end{array}$ \\
\hline
\end{tabular}

Source: Reference 8.

(correlation of $0.527, P<0.05$ ). The local contribution varies with municipal income for the wealthiest decile while the central contribution is the same for all municipalities. There is no clear pattern on the part of the central authorities to direct expenditures toward the poorest municipalities.
The equalization fund in Chile, called the Municipal Common Fund (MCF), modified the inequality of spending for health and other municipal services. The MCF collected $60 \%$ of property tax revenues from all municipalities, and wealthier municipalities provided an additional contribution from industrial and commercial permit revenues. The moneys were then redistributed to municipalities according to a per capita allocation formula based on geographic and poverty indicators. Table 2 shows how municipal income and distribution were affected by the fund. The Gini coefficient, 
TABLE 1. Expenditures on municipal primary health care per beneficiary in Chile, 1996 (averages by deciles of municipal income, in pesos) ${ }^{\text {ab }}$

\begin{tabular}{lccc}
\hline \multicolumn{1}{c}{ Deciles } & Total expenditure & Central government contribution & Local contribution \\
\hline 1 (poorest) & 14479.5 & 10570.9 & 3681.6 \\
2 & 12160.8 & 9219.7 & 2748.1 \\
3 & 12205.0 & 8701.8 & 3543.9 \\
4 & 12678.5 & 9241.7 & 3325.9 \\
5 & 11608.2 & 8303.1 & 3221.5 \\
6 & 12286.3 & 8178.3 & 3754.6 \\
7 & 13826.3 & 9598.2 & 3889.8 \\
8 & 11677.5 & 8367.7 & 3158.2 \\
9 & 12231.0 & 8638.7 & 3121.4 \\
10 (wealthiest) & 23496.0 & 9479.2 & 12808.8 \\
\hline
\end{tabular}

Source: Reference 8.

a 1996 exchange rate, US $\$ 1.00=407$ Chilean pesos.

b The figures in the respective two columns on the right do not add up to the "Total" expenditure figures because there were additional minor nonspecific funding sources that were left out of the table for the sake of clarity.

As virtudes. Passados doze anos do início do processo de construção do SUS no Brasil, destacam-se alguns aspectos que poderiam ser considerados grandes avanços já alcançados. O principal deles é o fato de que o processo de descentralização da saúde tem sido o eixo condutor da reforma do Estado no Brasil e em alguns casos representa a sua própria estruturação. Dados recentemente divulgados pela Secretaria de Políticas do Ministério da Saúde revelam que, dos 5507 municípios brasileiros, 5343 (97\%) apresentam-se habilitados para a gestão de seu Sistema Local de Saúde, abrangendo 92\% da população do país. Pensando ainda de forma ampliada, isso representa pelo menos 5343 Conselhos Municipais e aproximadamente 100 mil cidadãos que participam em órgãos colegiados componentes do fluxo decisório das políticas públicas. Isto representa a configuração do processo de descentralização como forma de democratização do Estado. Da mesma forma, 5343 municípios estão recebendo recursos diretamente do Fundo Nacional de Saúde para o Fundo Municipal de Saúde, para a execução de seus Planos Municipais para esse setor.

Vários mecanismos vêm sendo criados para fortalecer iniciativas locais que buscam aprimorar o desenho do modelo assistencial do SUS. Um destes mecanismos tem sido o Programa Saúde da Família, que foi implantado a partir de 1994 e vem funcionando como estratégia estruturante da organização da atenção básica, buscando articular, no âmbito comunitário, os preceitos de ação local e integral com os princípios basilares do SUS. O Programa Saúde da Família tem-se configurado como parte integrante de uma política intersetorial centrada na produção social de saúde e como um modelo tecnoassistencial fundamentado em formas de racionalidade comunicativa e da produção de serviços e ações de saúde resolutivos e integrais.

Um dos elementos positivos deste processo está na sua forma de financiamento, uma vez que foi criado na NOB 01/96 um mecanismo de traspasse automático de recursos para custear ações básicas de saúde (o Piso de Atenção Básica), de acordo com um per capita nacional aplicado à população de cada município. Além disso, foram estabelecidos valores agregados ao Piso de Atenção Básica para estimular ações programadas tais como: a) Programa Saúde da Família; b) Programa de Combate às Carências Nutricionais; c) Vigilância à Saúde e d) Farmácia Básica. which measures income inequality on a scale of 0 (low inequality) to 1.0 (high inequality), showed an improvement in equity among the municipalities, going from .45 to .30 .

In Chile, there was some evidence of "fiscal laziness." This effect was due to the physical presence or absence of centrally administered primary services in some municipalities, rather than the differences in funding sources. Some municipalities in Chile had primary care services provided from the hospitals managed by the Ministry of Health, while other municipalities were the sole providers of primary care services. Municipalities that were fully responsible for the primary care in their geographic area provided more per capita resources to their target population than did municipalities that were responsible for only a portion of the population in their geographic area, sharing responsibility for care with nationally controlled and financed facilities. In Bolivia the data available for comparisons among municipalities was not of sufficient quality to provide a comparative analysis with Chile. The limited data that was analyzed for Bolivia did not show any meaningful relationships among factors that might explain differences in municipal revenue, spending, and utilization rates for health care services, such as visits per capita (9). Case studies of $17 \mathrm{mu}$ nicipalities in Bolivia found that better performance along the dimensions of equality, utilization, and quality at the local level was the result of individ-

TABLE 2. Distribution of municipal disposable revenue per inhabitant and Gini coefficient of inequality before and after reallocations of Municipal Common Fund (MCF), Chile, 1996

\begin{tabular}{lrr}
\hline & $\begin{array}{r}\text { Before MCF } \\
\text { reallocations }\end{array}$ & $\begin{array}{c}\text { After MCF } \\
\text { reallocations }\end{array}$ \\
\hline $\begin{array}{c}\text { Average revenue } \\
\text { (pesos) }^{\mathrm{a}}\end{array}$ & 24646 & 40823 \\
Gini coefficient $^{\mathrm{b}}$ & 0.45 & 0.30 \\
\hline
\end{tabular}

Source: Reference 8.

a 1996 exchange rate, US $\$ 1.00=407$ Chilean pesos.

b The Gini coefficient measures income inequality on a scale of 0 (low inequality) to 1.0 (high inequality). 
ual initiatives of particularly motivated officials. It was also found that local governments which followed the "new rules" of the decentralization policy had better performance than those that did not.

Municipalities in Bolivia without the leadership of motivated officials tended not to do as well. The importance of individual leadership may be due to the limited institutional capacity of local municipal governments, many of which were recently created. Since the Bolivian central Government is not as able as the one in Chile to enforce the rules of decentralization, these findings suggest that the institutional capacity of a central government may also condition the effectiveness of decentralization. The findings also suggest that in weak States an additional effort should be made to strengthen the support and monitoring activities in the process of decentralization.

There were little data available to evaluate the efficiency and quality of services in the two countries. Case study interviews suggest that the quality of services has improved in both Bolivia and Chile due to the increased resources available. It is not clear how much decentralization itself contributed to this improvement.

As for securing a financially sound health system, the results were mixed. In Bolivia, the ability of local governments to shift resources to other priorities resulted in a financial crisis for health care that was later partially addressed by earmarking funds for that sector. In Chile, where the local governments are unable to go into deficit, and where they added locally generated resources to fund health, the system seems more financially sound.

\section{LESSONS FOR DECENTRALIZATION IN LATIN AMERICA}

The health systems in Bolivia and Chile are among the most decentralized in Latin America. However, our analysis suggests that, even with de-
Outro aspecto relevante desta NOB é que ela utilizou o conceito mais abrangente de saúde utilizado na Constituição de 1988, o que vem viabilizando um debate acerca da promoção da saúde. Destaca-se que, quando da realização pelo CONASEMS do XV Congresso de Secretários Municipais de Saúde, foi criada a Rede Brasileira de Municípios Saudáveis.

O SUS é responsável por uma população de cerca de 156 milhões de habitantes e convive com uma rede suplementar que atende 41 milhões de pessoas. É importante destacar ainda que $80 \%$ da rede de atenção primária e secundária de saúde no Brasil está sob a sua responsabilidade, além de praticamente toda a rede de alta complexidade. Isto demonstra que o processo de estruturação do SUS pode ser considerado como um movimento contra-hegemônico ao ajuste estrutural verificado hoje, ao promover um alargamento do Estado ao invés da tendência de construção do Estado mínimo observado em outros setores.

Os dilemas de um sistema entrando na adolescência. Vários são os problemas existentes neste processo, entre eles as diferenças entre os entes federativos. Dos municípios brasileiros, $40 \%$ possuem menos de $10 \mathrm{mil}$ habitantes, e apenas 0,6\% mais de 500 mil, chegando ao extremo de um município como o de São Paulo, que tem uma população de aproximadamente 9 milhões. Organizar um sistema que conviva com esta realidade diversa é sempre um grande empreendimento.

Outro grande desafio é a cruel realidade da desigualdade social brasileira. No ano de 1999, 85 milhões de brasileiros estavam vivendo abaixo da linha da pobreza e existiam mais de 8 milhões de desempregados.

A extensão da cobertura, principalmente da atenção básica, ocorrida com o processo de municipalização, evidenciou um grave problema de ordem qualitativa e quantitativa relacionado com os recursos humanos do setor. A falta de sintonia dos cursos de formação de profissionais de saúde com a realidade onde estes profissionais vão atuar é evidente e já bastante discutida.

É importante destacar que, embora já exista uma agenda setorial para aprimoramento do processo de descentralização, esta agenda deve ser fortalecida. Um dos importantes temas discutidos hoje é a redefinição do papel dos estados nesse processo. A União conseguiu promover de forma rápida uma remodelação de sua estrutura, organizando-se para uma nova realidade marcada pela descentralização dos recursos e pela desobrigação de prestar a assistência. Os municípios, em sua maioria, têm conseguido dar uma resposta, embora em níveis diferentes, no redesenho de seu papel na construção dos Sistemas Locais de Saúde. Já para os Estados, observa-se uma opacidade no seu real papel no SUS, também em intensidade diferente de Estado para Estado.

Uma melhor definição das fontes de financiamento do setor é outra importante pauta dessa agenda. Com a descentralização não ficou bem claro quais seriam essas fontes. Já se encontra em fase avançada uma Emenda Constitucional para definir as fontes orçamentárias para o setor da saúde nas três esferas de governo.

Acima de tudo é importante ter a clareza de que o Brasil vive hoje um dos mais ricos processos de descentralização/municipalização do setor da saúde, reconhecendo-se a necessidade de aprimoramento em algumas áreas e de criação de uma agenda que contemple esta discussão. Está se estruturando no Brasil um SUS, fundado nos princípios da solidariedade e da justiça social. 
centralization, municipalities in both countries have a relatively restricted range of choice, and that even that range of choice has been reduced over time. We have also found no clear evidence that these limited degrees of decentralization have had a strong positive or negative effect on health system performance. These findings suggest that decentralization policies in Latin America have not really tested the wide ranges of choice that might lead to local innovations that could improve the health systems.

The findings, however, do lead to some specific recommendations for new decentralization policies. When some mechanisms allow local communities to choose between health and other priorities, as in Bolivia, local governments can sharply reduce health spending. In this case, the central authorities then have the option of earmarking intergovernmental transfers to health in order to restore health funding. The Chilean case also shows that equalization funds can result in a more equal distribution of local allocations to health.

Acknowledgments. This research was supported by United States Agency for International Development Cooperative Agreement DPE-5991A-00-1052-00. The authors are solely responsible for the content of this article.

\section{REFERENCES}

1. Tendler J, Freedheim S. Trust in a rent-seeking world: health and government transformed in northeast Brazil. World Development 1994: 22(12);1771-1791.

2. Gonzalez-Block MA, et al. Health service decentralization in Mexico: formulation, implementation and results of policy. Health Policy Plan 1989:4(4);301-315.

3. Holly J. Estudio de descentralización de la gestión de los servicios de salud. Territorio de Capinota, Bolivia. Washington, D.C.: University Research Corporation; 1995.

4. Prud'homme R. The dangers of decentralization. The World Bank Research Observer 1995: 10(2);201-220.
5. Bossert T. Decentralization. In: Health policy and systems development: an agenda for research. Janovsky K, ed. Geneva: World Health Organization; 1996. pp. 147-160.

6. Collins C. Decentralization. In: Health policy and systems development: an agenda for research. Janovsky K, ed. Geneva: World Health Organization; 1996. pp. 161-178.

7. Bossert T. Analyzing the decentralization of health systems in developing countries: decision space, innovation and performance. Soc Sci Med 1998;47(10):1513-1527.

8. Bossert T, Larrañagua $\mathrm{O}$, Infante A, Beauvais J, Espinosa C. Applied research on decentralization of health systems in Latin America: Chile case study. Boston: Data for Decision Making Project, Harvard School of Public Health. Forthcoming.

9. Bossert T, Ruiz Maier F, Escalante S, Cardenas M, Guissani B, Capra K. Applied research on decentralization of health systems in Latin America: Bolivia case study. Boston: Data for Decision Making Project, Harvard School of Public Health. Forthcoming.

RESUMEN La descentralización constituye a menudo una parte importante de las políticas de reforma del sector de la salud. Sin embargo, ha habido pocos intentos de investigar comparativamente el grado de descentralización y los efectos de esta sobre la equidad de las asignaciones a la salud, de modo que desconocemos la mejor manera de poner en práctica esta reforma. En este estudio se utiliza un innovador análisis comparativo del "espacio de decisión" que se les concedió a las municipalidades en las reformas de la salud en Bolivia y Chile, dos países que han tenido varios años de experiencia en la puesta en práctica de la descentralización. El estudio reveló que a las autoridades locales se les concedió un espacio de decisión relativamente pequeño en funciones clave de los sistemas de salud. Asimismo, se verificó que las autoridades centrales a menudo reducen el espacio de decisión para dirigir más recursos a la salud o para restringir la elección local en cuestiones de recursos humanos. También se observó que se consiguieron asignaciones más equitativas de los fondos destinados a la salud, en Chile mediante un fondo común de igualación para las municipalidades y en Bolivia forzando la asignación a la salud de un porcentaje específico de las transferencias del gobierno central a las municipalidades. 